\title{
The Critical Barriers to the Balanced Scorecard Successful Implementation: Airlines Perspective
}

\author{
Azza Maher \\ Tourism Studies Department - University of Sadat City
}

\begin{abstract}
Both prior literature and reported managerial practices have claimed that the Balanced Scorecard (BSC) is a management tool that can help organizations to effectively implement strategies. Despite its worldwide popularity and its recognition as a powerful management tool, the BSC is not always used successfully. Although many organizations have adopted the BSC, a great number of them have encountered problems when trying to introduce the concept in their business. The purpose of this paper is to explore the critical barriers and threats which may cause the BSC initiatives to fail in the airline industry. Moreover, the research aims at identifying the areas with the critical measures which are difficult to be applied and need more attention during implementing the BSC. In order to achieve this, a questionnaire form is designed and distributed, 312 questionnaires in 104 airlines companies, through e-mail, 205 valid forms have been returned back with a response rate of $65.7 \%$. Based on the study results, the usage of common measures among the performance measures perspectives during the BSC implementation indicates that the most common measures found are in the financial perspective, then with less common usage are the measures in the customer perspective and learning and growth, while quite far away are the measures used in the internal business processes perspective. In addition, the results reveal that the most critical barriers associated to implementing the BSC are "common measure bias" and "obese and static nature". Furthermore, the results show that "ambiguous validity of the cause and effect relationship barriers" and "general requirements barriers" have achieved a moderated negative effect. On the contrary, the barriers "strategic control", "cultural barriers", and "matching barriers" are ranked as the least critical barriers.
\end{abstract}

Keywords: Balanced Scorecard (BSC), Financial and non-financial measures, Performance measurement, Airlines.

\section{Introduction}

In today's world, businesses are in search for alternative management systems in order to have an effective performance system. One of the strategic management tools used in the name of an effective performance management is called the Balanced Scorecard (BSC). The BSC method was proposed by Kaplan and Norton in 1992. (1) The BSC developed by (Kaplan and Norton, 1992) is the most popular framework in the area of performance measurement. The introduction of the BSC has been mainly based on a transition from the traditional financial performance measurement systems towards a more balanced approach (financial and nonfinancial measures) that includes several measures in a multi-dimensional structure. ${ }^{(2)}$

Furthermore, many researchers argue that the BSC is a major performance measurement system for many industries because it provides a broad performance measurement of both financial and non-financial perspectives. ${ }^{(3,4,5)}$ Also, the study of Frigo and Krumwiede has concluded that the BSC method has experienced an increase in popularity as a performance measurement system for translating an organization's mission into goals, aligning individual and organizational goals and actions and performance measures, and measuring processes related to goal achievement. ${ }^{(6)}$ In addition, the BSC is one of the most highly rated management tools today. ${ }^{(7,8)}$

The BSC, which refers to the measurement method driving future performance, is a set of performance evaluation tools developed to accomplish the corporate vision and strategy. Through its four dimensions, i.e., financial, customer, internal business processes, and learning and growth, the BSC assesses the organizational operational performance, integrates the internal physical and intangible assets of the enterprise, and expects to establish a strategic performance evaluation system in accordance with cost efficiency. ${ }^{(9)}$ 
Moreover, what makes the BSC method different from other performance measurement and evaluation methods is that it expresses the strategies of the company in a variety of score card sizes. Thus, it achieves the elimination of the strategies that do not serve any purpose (useless strategies) in the upper size. However, in order to apply the BSC successfully, all the sizes and strategies must be balanced with suitable rates. There is no consensus on the score card sizes and rate level of the strategies identified in each level and which method to be used to rate in practice. ${ }^{(1)}$

Since its early development, the BSC has been used successfully as a strategic management tool in a range area of domains. Whereas, five years ago, implementations were at business units and divisions, today the implementations of the model are seen at the corporate level and reflected in the entire activity of the organization. Non-profit organizations have started to use it, including companies in the healthcare sector and the public sector. Moreover, government organizations around the world are adopting the concept. As for the airline industry sector, there is limited literature focusing on this subject. ${ }^{(10)}$

Nowadays airline companies face crucial stages of development programs; one of the most important parts of a development program is measuring performance. Therefore, in this context, the BSC is believed to show the performance results in a more accurate and complete way. ${ }^{(11)}$ However, there are numerous possible barriers and threats that deserve increased attention from both researchers and top managers.

The purpose of this paper is to fill a gap in the BSC literature by going a step further and exploring the critical threats and barriers which may cause the BSC initiatives to fail in the airline industry. Moreover, the research aims at identifying the areas with the critical measures which are difficult to be applied and need more attention during implementing the BSC. In order to achieve this, the study investigates if there is a significant difference in the usage of common measures among performance measures perspectives. This article is organized as follows: A review of the research literature related to the BSC concept, four perspectives of the BSC, implementation stages, advantages and disadvantages of implementing the BSC and Barriers to Implementing. Also, the research methodology is described in the second section, while the results obtained from the data analysis are discussed in the third section. Managerial implications and conclusions are introduced in the fourth section.

\section{The BSC Concept}

Leading organizations agree on the need for a structured methodology for using performance measurement information to help set agreed-upon performance goals, allocate and prioritize resources, inform managers to either confirm or change current policy or program direction to meet those goals, and report on the success in meeting those goals. ${ }^{(12)}$ Traditionally, business management has been based on financial indicators. In fact, during the industrial age, economic and financial information became almost the sole instrument used to facilitate the decision-making process in the business world. However, with the arrival of the technology revolution, it has become clear that a wider range of information is needed, and consequently qualitative and descriptive data has begun to be more highly valued. ${ }^{(13)}$

Therefore, in response to this need for new forms of information, Kaplan and Norton, professors at Harvard Business School, have developed a methodology to assess management and organizational performance. They have called it the Balanced Scorecard (BSC). Unlike its predecessors, this model incorporates both financial and non-financial indicators. As a result of the success of this model when applied in the private sector, where it was first tested, studies have been done on how to adapt it to be used in the public sector and in non-profit organizations. ${ }^{(14)}$

Historically, the BSC was elaborated and fine-tuned by Robert Kaplan and David Norton in the 1990s, arising from the need to incorporate more than merely historical accounting scorekeeping to management. The phrase "Balanced Scorecard" was coined in the early 1990s but the concept originates from the pioneering performance management work of General Electric in the 1950s. ${ }^{(15)}$ The "Balance" in the BSC relates to three areas that are neglected in the traditional financial performance business model ${ }^{(16)}$ 
- Balance between financial and non-financial indicators of success

- Balance between internal and external stakeholders

- Balance between lag and lead indicators of success

In an attempt to over-depend on financial measures, Robert Kaplan and David Norton have added three non-financial dimensions for the evaluation of firm performance: Customers, internal business processes, and learning and growth, hoping that the new complete measurement system would aim at the goals of corporate vision. They also argue that the BSC should be integrated into firms' action plans, strategies, and visions. The design of the four dimensions deliberately coordinates with the business functions of a firm. More concisely, the financial dimension is associated with the accounting function of the organization, the customer dimension with the marketing function, the internal business processes with the integral value chain, and the learning and growth dimension with the human resources. Meanwhile, these four dimensions share the resources that a firm should input and the functions that a firm should have. ${ }^{(17)}$

However, the BSC translates a company's mission and strategy into a set of performance measures that form the base for a measurement and strategic management system. ${ }^{(18)}$ Despite the system measures and preserved traditional financial measures, the system directs the financial measures with perspectives that they stimulate for a future performance, including financial objectives of short, medium, and long term, to the desired economic result to be reached, reflecting the companies life cycle to evaluate if it has possibility of growth, maintenance, and collect of the strategy. ${ }^{(19)}$

Furthermore, the BSC is a communication tool that helps each employee better understand where the strategy drives the organization, what the plan is for reaching that destination, and what their departmental and individual measured contribution is to that convergent effort. Hence, with such understanding, the employees whether directly involved in the planned strategy execution, or not - can also change and improve the way they perform their daily jobs through micro-decisions that are both convergent and complementary to the execution of the organization's strategic plan. ${ }^{(20)}$

Generally, the BSC has the function to get organizational consensus, focus the strategy, and communicate to all the company members the strategic management. The BSC structure pursues clear and simplified stages of involving definition of objectives, pointers, goals and action, and later the representation of the strategic maps in cause and effect diagrams. Normally, a BSC contemplates from 20 to 25 objectives, which can provide to the manager an agreement and a strategy measurement of the company. Moreover, each objective is constructed around different pointers of performance. ${ }^{(19)}$

\section{The Four Perspectives of the BSC in the Airlines}

As mentioned above, the BSC tries to translate a company's strategic direction and objectives into actionable initiatives and measurements. Obviously, using only the financial measurement is not enough to drive an organization. ${ }^{(21)}$ As a result, the original BSC designed by Kaplan and Norton identifies four perspectives. The four perspectives are: The customer perspective, the internal business processes perspective, the learning and growth perspective, and the financial perspective (illustrated in Figure 1). ${ }^{(21)}$ Therefore, the BSC enables organizations to monitor the intangible assets needed for future growth. ${ }^{(22)}$

For each of the four components the manager would have to establish goals and then translate these goals into specific measures. The BSC includes financial measures that tell the result of actions already taken. It also complements the financial measures with operational measures on passenger satisfaction, internal business processes, and the organization's innovation and improvement activities. All these operational measures can be seen as the drivers of future financial performance. ${ }^{(23,24)}$ 


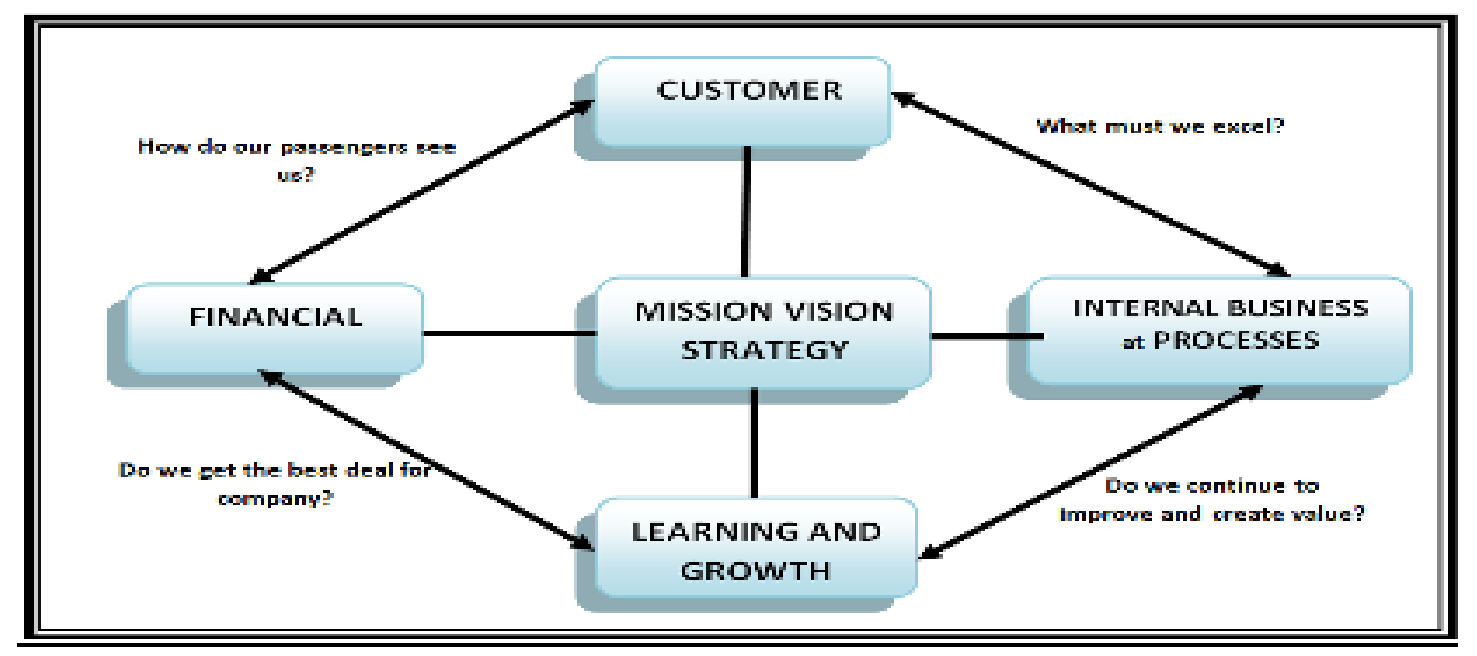

Figure (1): The BSC strategic perspectives

Source:(Modified from Procurement Executives' Association, 2003). ${ }^{(12)}$

In summary, the four perspectives enable airlines to gain a holistic view of performance measurement. These perspectives are explained as follows ${ }^{(24)}$ :

- Financial perspective: It indicates whether an airline's strategy, implementation and execution are contributing to bottom-line improvement. Financial objectives typically relate to profitability.

- Customer perspective: It provides a way for managers to identify the passenger and market segments in which the business unit will compete and the measures of the business unit's performance. The core outcome measures include passenger satisfaction, passenger retention, new passenger acquisition, passenger profitability, and market and account share in targeted segments.

- Internal business (processes) perspective: Executives use it to identify the critical internal business processes in which the airline must excel. These processes enable the business to deliver the value proposition and satisfy shareholder's expectations of excellent financial returns. This perspective includes both innovation and operations.

- Learning and growth perspective: It identifies the infrastructure that the airline must build to create longterm improvement. Businesses are unlikely to be able to meet their long-term targets for customers and internal business processes using existing capabilities. Therefore, in order to bridge these gaps, businesses will have to invest in re-skilling employees, enhancing information technology and systems, and aligning organizational procedures and routines.

\section{The BSC Implementation Stages}

Researchers identify four major stages in implementing a BSC. The first stage is clarifying and translating the vision and strategy; it is generally accomplished by a team of upper management. The purpose of this phase is to develop an understanding of the firm's mission and strategy for obtaining its goals. Since mission statements are often vague, the management should translate the mission into specific objectives and then develop a strategy that will use the firm's strength to meet the objectives ${ }^{.(25,26)}$

In addition, the organization in this stage draws its strategy map. A strategy map is a framework with a common language that visualizes and communicates a strategy and the according processes and systems necessary to its realization. It is a direct extension of the BSC as it depicts critical objectives and relationships identified in the BSC process. ${ }^{(27)}$

After the firm's BSC has been developed, each strategic business unit determines measures for its own scorecard as a part of the second stage, communication and linking. In this stage, it is required that people in the different units through out the organization develop a scorecard for their particular segments of the business. 
In the remaining stages of the BSC implementation, managers set targets and budgets as a third step; and over time, the last stage is receiving feedback on the strategies of the business units and the firm by evaluating performance relative to scorecard measures ${ }^{.(27)}$

\section{Advantages and Disadvantages of Implementing the BSC}

The theory of the BSC has at least two advantages over the traditional approach to performance evaluation. First, the BSC is a complete, compound tool for evaluating firm performance with four dimensions, including finance, customer, internal business processes, and learning and growth. These four dimensions could not only be seen as performance measures, but also as corporate input resources. Second, the BSC shifts the conventional focus on physical assets to the emphasis on both physical and intangible resources in a firm for the purpose of corporate long-term development. Therefore, the BSC is constructed to be a full-range framework for performance evaluation to meet the corporate's goal of perpetual growth. ${ }^{(28)}$

Moreover, the BSC is a performance measurement matrix designed to capture financial and nonfinancial metrics that provide insight into the critical success factors for an organization, effectively aligning organization strategy to key performance objectives. The BSC helps organizational leaders through providing balance from two perspectives. First, it ensures an appropriate mix of performance metrics from across the organization to achieve operational excellence; thereby, the BSC ensures that no single or limited group of metrics dominates the assessment process, possibly leading to long-term inferior performance. Second, the BSC helps leaders offset short term performance pressures by giving recognition and weight to long-term company needs that, if not properly addressed, might jeopardize future company performance. ${ }^{(15)}$

Generally speaking, the BSC can help organizations achieve better results when compared to traditional performance measurement system. ${ }^{(29)}$ In addition, it is valuable to mention that implementing the BSC in an airline company-wide will provide a common methodology and coordinated framework for all company performance measurement efforts. ${ }^{(8)}$

While implementing the acquisition BSC is an important first step, helping agencies to develop the BSC for additional functions (e.g. programs, human resources, finance, IT), it will also strengthen the link among the acquisition system, those additional functions, and agency missions and goals. This will promote crossfunctional coordination of improvement efforts and break down "stovepipes" in the company. The BSC will also provide sound data on which to base business decisions, from allocation of available resources to future direction. ${ }^{(18)}$

However, many researchers have criticized the limitations of the BSC. For example, the BSC applies a large number of variables that create complex optimization problems. ${ }^{(30,31)}$ Moreover, others argue that the BSC does not provide a common scale of measurement, and it lacks a standardized baseline or benchmark to compare performance. ${ }^{(32)}$ Not surprisingly, the number of problems encountered using the BSC is what gives its complexity.

Relative performance evaluation in the BSC framework requires decision makers to evaluate multiple performance measures (16-28) for two or more strategic business units. In order to subjectively formulate a solution, decision makers should understand the relationships between performance measures and their relevance to the overall strategy. Furthermore, recognition of the relationships between temporally-separated (i.e. leading and lagging) performance indicators and non-linear relationships arising from non-financial measures places extra cognitive demands on memory and attention. ${ }^{(33)}$ Given the number of measures and the complex nature of their relationships, a human decision maker cannot make a decision analytically. Since there is no objective or computational procedure available, decision makers should spend time thinking about what to do and searching for solutions. Besides, graphical representation can facilitate problem comprehension by summarizing information and providing an overall perspective in complex, less analyzable tasks. ${ }^{(34)}$ 
Furthermore, the study of Rickards ${ }^{(31)}$ has concluded that the BSC does not have a mathematical model or a weighting scheme. Other studies also mention that the BSC does not have a comprehensive index to review the interaction between measures of performance. ${ }^{(33,34)}$ Additionally, several studies have been conducted to solve these limitations of the BSC, and researchers have found that Data Envelopment Analysis (DEA) can complement the complexities of the BSC. ${ }^{(35,36,37)}$

\section{Barriers to Implementing the BSC}

Although many different organizations are using the BSC as a management technique to implement corporate strategy, a number of them have encountered different problems when trying to introduce the concept in their business. The majority have either implemented the BSC but without any significant improvement in performance, or they have given up during the implementation process itself. ${ }^{(21)}$ ). Therefore, many researches have discussed the barriers to implementing the BSC. ${ }^{(21,38,39,40,41,42,43)}$ The BSC is a tool to facilitate communication within the process of translating the corporate strategy. If the BSC is used only as a tool for measuring and monitoring performance in the dimensions incorporated in it, without implementing the related process, this will restrict the effectiveness of the Scorecard and it is more likely to fail. ${ }^{(40,42)}$

According to the study of Olve et al. ${ }^{(40)}$, the absence of executive sponsorship will harm every BSC initiative. Also, top managements should stand behind such an initiative since the BSC is a tool for executing the company's strategy. In addition, the top management should explain to the other members of the firm why the BSC is so important. Due to limited budgets or the perceived simplicity of the tool, the BSC education and training are very often preserved only for high-level managers or only for project team members. The study of Niven ${ }^{(44)}$ stresses that the development of the BSC requires a precise development plan to guide the selected team during the BSC journey. Besides, without a formal plan showing the implementation path in advance, there is the risk of confusion. Even if there is high interest among employees and a readiness to collaborate, a lack of organization may lead to failure ${ }^{(45)}$.The BSC plan should, as Nuven's study ${ }^{(44)}$ believes, reveal to everyone in the organization what is planned to be achieved, with whom, why, how, and how long it will take.

The reported high failure rate of the BSC along with the mixed research findings about its effectiveness have resulted in questions about the validity of some assumptions underpinning the BSC ${ }^{(25,46 ; 47)}$. Based on these studies, Table (1) summarizes the main limitations associated with implementation of the BSC:

Table (1): Limitations in implementation of the BSC

\begin{tabular}{|c|c|c|}
\hline $\begin{array}{c}\text { Problems associated } \\
\text { with implementing } \\
\text { the BSC }\end{array}$ & $\begin{array}{l}\text { Description of the } \\
\text { problems }\end{array}$ & Symptoms to look for \\
\hline $\begin{array}{l}\text { Ambiguous validity } \\
\text { of the cause-and- } \\
\text { effect relationship }\end{array}$ & $\begin{array}{l}\text { It is argued that there is no } \\
\text { cause-and-effect } \\
\text { relationship among the four } \\
\text { perspectives of the BSC }\end{array}$ & $\begin{array}{l}\text {-Improving customer perspectives (e.g. customer satisfaction) does } \\
\text { not necessarily improve financial outcomes because satisfied } \\
\text { customers may still choose to buy products from other companies } \\
\text { - Non-financial measures in the BSC are not necessarily the drivers } \\
\text { of financial measures } \\
\text { - Organizations often fail to establish such causal links among the } \\
\text { four perspectives because there is little or no guidance given in the } \\
\text { BSC literature on how to set up these causal relationships }\end{array}$ \\
\hline $\begin{array}{l}\text { Strategic control } \\
\text { barrier }\end{array}$ & $\begin{array}{l}\text { It is argued that the BSC is } \\
\text { a hierarchically top-down } \\
\text { model that is not rooted in } \\
\text { the organization or in the } \\
\text { environment, thus making } \\
\text { it questionable as a } \\
\text { strategic control tool }\end{array}$ & $\begin{array}{l}\text { - The measures in the BSC are defined by top managements with } \\
\text { little involvement of frontline workers; thus, employees can only } \\
\text { react rather than act on their own } \\
\text { - The BSC does not reflect changes in external environment } \\
\text { because it has no direct relationship with the market } \\
\text { - The BSC gives inadequate feedback on the content of the strategy }\end{array}$ \\
\hline
\end{tabular}




\begin{tabular}{|c|c|c|}
\hline $\begin{array}{c}\text { Common measure } \\
\text { bias }\end{array}$ & $\begin{array}{l}\text { It is found that not all the } \\
\text { measures in the BSC are } \\
\text { treated equally during the } \\
\text { performance evaluation } \\
\text { process }\end{array}$ & $\begin{array}{l}\text { - Superior managers tend to simplify performance measurement by } \\
\text { only relying on common measures when they evaluate the } \\
\text { performance of multiple subordinate units } \\
\text { - Unique measures are often disregarded or even ignored by superior } \\
\text { managers in performance evaluations }\end{array}$ \\
\hline $\begin{array}{c}\text { Obese and static } \\
\text { nature }\end{array}$ & $\begin{array}{l}\text { It is suggested that the } \\
\text { implementation of an } \\
\text { obese and static BSC may } \\
\text { potentially risk } \\
\text { performance management }\end{array}$ & $\begin{array}{l}\text { - The fact that there are too many measures in a BSC system is not } \\
\text { consistent with a psychological research finding suggesting that } \\
\text { human beings have difficulty handling more than seven measurements } \\
\text { simultaneously } \\
\text { - The BSC is a static model because it cannot solve the time lag } \\
\text { problem and does not reflect changes in external environments }\end{array}$ \\
\hline Matching barriers & $\begin{array}{l}\text { Matching problems with } \\
\text { the existing planning } \\
\text { systems, performance } \\
\text { measurement systems, and } \\
\text { IT systems of their local } \\
\text { partners }\end{array}$ & $\begin{array}{l}\text { - Under existing performance measurement systems, managers usually } \\
\text { need to achieve several objectives, which tend to make them focus } \\
\text { more on short-term benefits rather than on the BSC's long term goals } \\
\text { - The IT systems in many local firms usually contain only financial } \\
\text { data, and thus cannot provide enough support for the implementation } \\
\text { of the BSC }\end{array}$ \\
\hline Cultural barriers & $\begin{array}{l}\text { Cultural values_-such as } \\
\text { Confucianism, high power } \\
\text { distance, and low } \\
\text { individualism may cause } \\
\text { problems when using the } \\
\text { BSC in China }\end{array}$ & $\begin{array}{l}\text { - Local managers, who tend to place more emphasis on long-term } \\
\text { relationships (guanxi) and who are accustomed to a more flexible } \\
\text { and informal management style may be hesitant to implement a } \\
\text { strict and formal BSC system } \\
\text { - } \quad \text { Employees' culture may reflect low individualism, which often } \\
\text { symbolizes emotional reliance on the group. Thus, when the BSC } \\
\text { encourages competition between individuals, local employees may } \\
\text { be reluctant to participate because they prefer group-based } \\
\text { activities and rewards }\end{array}$ \\
\hline
\end{tabular}

Source: (Modified from Zeng \& Luo; 2013). ${ }^{(38)}$

\section{Methodology}

A quantitative research method is employed in this research due to a number of reasons. First, it is one of the most widely used techniques to reach a large population and to identify and describe the variability in different situations. Second, the collected data later on can be analyzed effectively through the SPSS program. ${ }^{(48)}$

\section{Research Design}

To achieve the purpose of this paper, a suggested framework of the BSC performance measures was develpoed to study whether there is a significant difference in the usage of common measures among performance measures perspectives during the implementation of the BSC in order to determine the critical areas. Moreover, the study attempts to identify the critical barriers which may cause the BSC initiatives to fail in the airline industry. In order to reach the goals of the paper mentioned above, the study is conducted at five stages (as shown in Figure 2): 


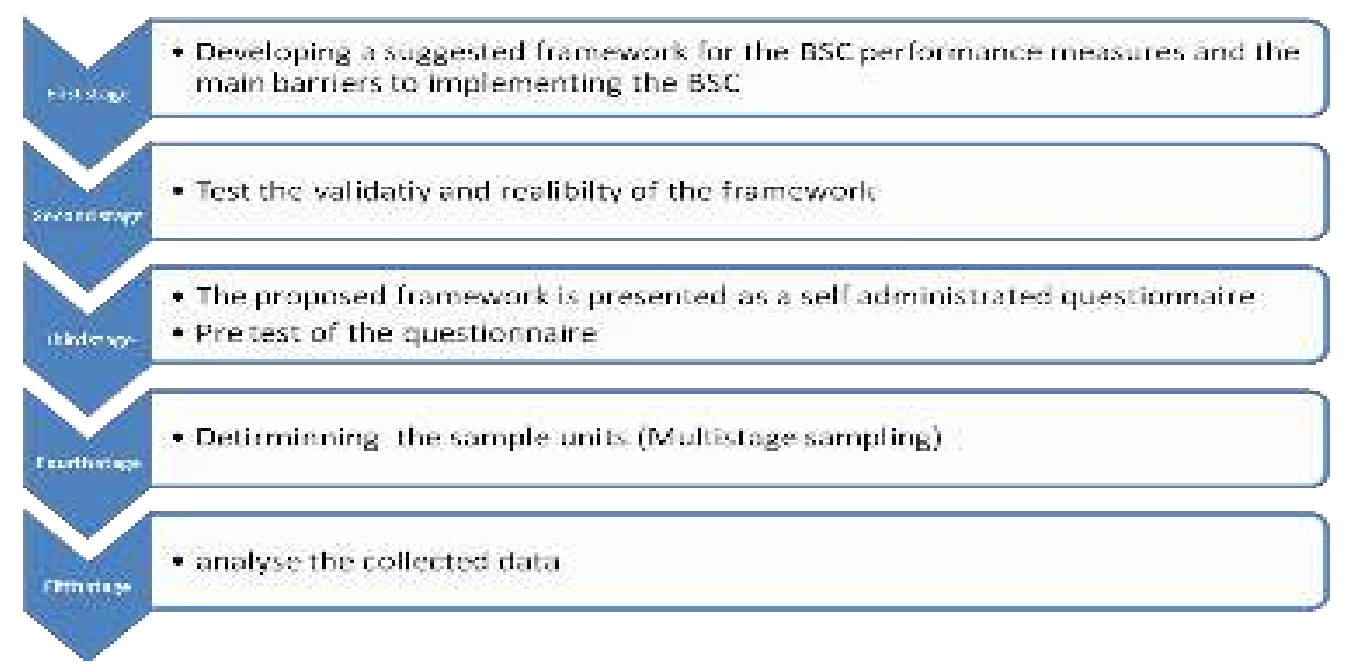

Figure (2): Methodology framework for field study (Research design)

The measures items collected are extracted from a number of published practitioner and academic literature concerned with the BSC implementation. ${ }^{(25,49,50,51,52,53,54)}$ On the other hand, the barrier items are built on preceding studies. ${ }^{(21,38.39,40,41,42,43,45,46)}$

In the first stage, measures that are not relevant to the four perspectives of the BSC have been deleted, based upon the definitions of each perspective as well as the researcher's own understanding of the content area. Furthermore, to increase credibility, the collected measures are identified and categorized by two executive managers in airlines companies. For judging the reliability of the sub drivers and measures, classification kappa statistics have been calculated to measure the agreement between the two raters ${ }^{(55)}$.

The equation for $\kappa$ is:

$$
\kappa=\frac{\operatorname{Pr}(a)-\operatorname{Pr}(e)}{1-\operatorname{Pr}(e)}
$$

Where $\operatorname{Pr}(\mathrm{a})$ is the relative observed agreement among raters, and $\operatorname{Pr}(\mathrm{e})$ is the hypothetical probability of chance agreement, using the observed data to calculate the probabilities of each observer randomly saying each category. If the raters are in complete agreement then $\kappa=1$. If there is no agreement among the raters (other than what would be expected by chance) then $\kappa$ group $\leq 0$ (55). The classifications of collected measures is compared by an inter rater reliability analysis using the kappa statistics which is performed to determine consistency among researchers. The inter-rater reliability for the raters was found to be Kappa $=0.94$.

Through the above process, 67 initial items have been generated in attempting to cover the four perspectives of the BSC: Financial perspective (11 items), customer perspective ( 8 items), internal business processes perspective (20 items), and learning and growth perspective (14 items).

On the other hand, 27 items have been generated through an exhaustive search to cover the barriers which may face the companies during implementation of the BSC: Strategic control barriers (4 items), ambiguous validity of the cause and effect relationship barriers (4items), common measure bais ( 2 items), obese and static nature (4 items), cultural barriers (3 items), matching barriers (3items), and general requirements barriers (7 items). 


\section{Data Collection}

\section{Research Instrument}

A suggested framework of the BSC performance measures and the main barriers of implementation is presented as a self administrated questionnaire. This questionnaire instrument consists of three sections: The first section is designed to elicit demographic information about the respondents and airline companies. The second section measures the usage of the four perspectives measures of the BSC in performance measurement. The third section identifies the critical barriers which might be considered during the BSC implementation. In the third section also the questionnaire uses a five-point Likert scale as a measuring scale and the respondents have had to indicate the extent of agreement or disagreement with a specific statement.

The researcher has been required to show an introductory letter to all potential respondents when soliciting participation in the research. As indicated in the introductory letter, the right of anonymity and confidentiality is guaranteed. This includes the assurance that the study is only for academic purposes and not for circulation to other parties. Moreover, because the respondents may have different frames of reference for the $\mathrm{BSC}$, a clear definition of the BSC is also provided to the respondents, and they have been instructed to answer all the questions based on that definition.

Furthermore, based on the research questions and size of the population, an e-mail survey has appeared to be the most economical and appropriate method of data collection. In addition to the low-cost consideration, e-mail surveys give people flexibility and more time to answer questions.

The initial questionnaire is prepared and a pre-test has been conducted and presented to a number of samples $(\mathrm{N}=15)$ of managers who have an experience with the BSC. The purpose of the pre-test is to detect any potential problems in the questionnaire design, clarity, or wording. Also, managers have been asked to complete the questionnaire and give their overall comments about the questionnaire. Based on the mangers' comments, one revision has been made and several items are reworded after the pilot exercise to improve the comprehensibility and clarity of the questionnaire instrument.

The pre-test respondents have suggested some changes in the form. Through this process, items which were not clear, or were not relevant to the research problem, have been re-worded or deleted.

The participants in the e-mail questionnaire are asked to take part in the study only after they have provided their consent. This consent has been returned to the researcher in a number of ways including, but not limited to, via fax or snail mail (a signed form that has been sent as an e-mail attachment), e-mailing back a signed form, or simply replying via e-mail affirmatively to an invitation to participate by stating in the message that the consent form has been read and agreed to. All questionnaire materials are sent together to the participants in one e-mail including the invitation for participation, background information about the researcher, consent form, instructions, and the questionnaire schedule.

The respondents have been given six weeks, including the follow up period, to respond to the questionnaire documents sent via e-mail. A follow up e-mail has been sent four weeks later and they have been given two weeks to return them. Some interviews have been conducted using Skype, a free software application that allows users to make voice calls over the internet. The received e-mail documents are reviewed manually in order to collect the data. Then, every e-mail is saved into separate word file. After that, a preprocessing procedure is carried out in order to identify the findings.

\section{The Target Population and Sampling}

The target population for the study is the airline companies. The sample of airline companies is selected through an exhaustive search through airline companies' websites lists under the airline directories of Yahoo and Google. The names and e-mails of the population have been acquired from the World Airline Directory ${ }^{(56)}$ which divides 
the airline companies according to 12 regions of the world. The World Airline Directory is a comprehensive database of more than 2,000 currently operating international, regional, and domestic airlines throughout the world.

The data in this research is collected using the multistage sampling method, since the proportional quota sample is appropriate to be used in the first stage. The quota sample improves the representation of particular strata (groups) within the population, as well as ensuring that these strata are not over-represented; ${ }^{(57)}$ in other words; it selects individuals as they come to fill a quota by characteristics proportional to populations. In order to create a quota sample, the researcher has specified the minimum number of sample units in each region which are concerned with having numbers that match their proportions in the population. In the second stage, the sample units of each region have been selected randomly as every company is given equal opportunities of being selected.

The questionnaires were distributed from August 1 to December 25, 2014. The following table shows the number of distributed questionnaires and valid questionnaires:

Table (1): Sampling process: Selected sample breakdown by region and response rate

\begin{tabular}{|c|c|c|c|c|}
\hline Region & $\begin{array}{c}\text { No. of airline } \\
\text { companies included in } \\
\text { the sample }\end{array}$ & $\begin{array}{c}\text { Distributed } \\
\text { questionnaires }\end{array}$ & $\begin{array}{c}\text { Number of valid } \\
\text { questionnaires }\end{array}$ & $\%$ \\
\hline $1-$ Africa & 25 & 75 & 56 & $74.6 \%$ \\
\hline $2-\quad$ The Caribbean & 12 & 36 & 26 & $72 \%$ \\
\hline $3-$ Central America & 4 & 12 & 7 & $58 \%$ \\
\hline $4-$ Central Asia & 5 & 15 & 8 & $53 \%$ \\
\hline 5- Europe & 22 & 66 & 49 & $74 \%$ \\
\hline 6- The Far East & 4 & 12 & 5 & $41.6 \%$ \\
\hline $7-$ Indian Sub & 4 & 12 & 7 & $58 \%$ \\
\hline Continent & 7 & 21 & 12 & $57 \%$ \\
\hline 9- The Middle East & 4 & 12 & 5 & $41.6 \%$ \\
\hline 10- Oceania & 4 & 12 & 7 & $58 \%$ \\
\hline $11-$ South America & 7 & 21 & 13 & $61.9 \%$ \\
\hline $12-$ Southeast Asia & 6 & 18 & 10 & $55.5 \%$ \\
\hline Total & 104 & 312 & 205 & $65.7 \%$ \\
\hline
\end{tabular}

The 312 questionnaires are distributed to a selected group of 104 international airline companies. From the 312 questionnaires distributed, 223 responses have been collected (for a response rate of 71.5\%). Moreover, to control the response bias, the data has been screened. After eliminating those with missing information and extreme answers, 205 usable responses have remained (usable response rate of 65.7\%).

\section{Data Analysis}

Data and information in this study are analyzed and discussed in accordance with the research objectives. The Statistical Package for the Social Sciences (SPSS, v17.0) is used to analyze the data obtained in this study. Descriptive statistics including simple frequencies, mean ratings, standard deviation and Cronbach alpha coefficients (for the testing of the reliability of the questionnaire) are computed. Furthermore, the Kruskal-Wallis test is used to test the median differences between groups; this test is similar to a one-way ANOVA test, yet it is a non-parametric test based upon rank or ordinal data for showing whether the obtained results are particular to the governorate-based activities or to the sample as a whole (the level of significance used is also $(\mathrm{P}<0.05)$ ). 


\section{Findings and Discussion}

\section{Sample Characteristics}

A total of 205 out of 312 airlines companies have completed the questionnaire in the survey period representing a response rate of $\mathbf{6 5 . 7 \%}$. Table (2) shows the demographic characteristics of the sample units. The highest percentage of the respondents is Regional Financial Managers (45.4\%); there is $45 \%$ of the sample network airline; only $14 \%$ is low cost and $16 \%$ is regional airline. The rest of the sample $(25 \%)$ is categorized as charter airline. The labor power of 114 airline companies (55.6\% of the sample) is more than 2500 employees, while 67 of them (6\% of the sample) are within the range of 2000-2500 employees. Companies that employ less than 2000 employees represent only $11.7 \%$ of the sample. Table (2) also illustrates that more than half of the companies have income level more than 1 billion US \$.

Table (2): Characteristics of the sample (Airline companies)

\begin{tabular}{|c|c|c|}
\hline Variable & Frequency & Percentage (\%) \\
\hline \multicolumn{3}{|l|}{ 1- Respondents } \\
\hline Regional General Manger & 11 & 5.4 \\
\hline $\begin{array}{lll}\text { Assistant } & \text { Regional General } \\
\text { Manager } & & \end{array}$ & 12 & 5.8 \\
\hline Operating Manager & 37 & 18 \\
\hline Regional Financial Manager & 93 & 45.4 \\
\hline Decision Maker & 52 & 25.4 \\
\hline \multicolumn{3}{|l|}{ 2- Airline company's type } \\
\hline Network airline & 92 & 45 \\
\hline Low cost & 29 & 14 \\
\hline Charter airline & 52 & 25 \\
\hline Regional airline & 32 & 16 \\
\hline \multicolumn{3}{|l|}{ 3-Labor power } \\
\hline Less than 2000 employees & 24 & 11.7 \\
\hline 2000-2500 employees & 67 & 32.7 \\
\hline More than 2500employees & 114 & 55.6 \\
\hline \multicolumn{3}{|l|}{ 4-Gross revenue } \\
\hline Less than 500 million US \$ & 29 & 14 \\
\hline 500 million-1 billion US $\$$ & 72 & 35 \\
\hline More than 1 billion US $\$$ & 104 & 51 \\
\hline \multicolumn{3}{|c|}{ 5- The main measuring performance methods have: } \\
\hline \multicolumn{3}{|l|}{ Qualitative characteristics } \\
\hline Quantitative characteristics & 205 & 100 \\
\hline \multicolumn{3}{|c|}{$\begin{array}{l}\text { 6- Basic standards used by companies for designing performance } \\
\text { measurement: }\end{array}$} \\
\hline Vision & 178 & 87 \\
\hline Mission & 201 & 98 \\
\hline Strategy map & 203 & 99 \\
\hline Other & 30 & 14.7 \\
\hline
\end{tabular}


The results above indicate that almost all the sample measures performance by using quantitative methods. However, only 87 airline companies use qualitative methods (42\% of the sample) to measure their performance. In addition, a reasonable number of airline companies have its mission ( $98 \%$ of the sample) and vision ( $87 \%$ of the sample) as basic standards to design performance measurement, while approximately all the companies use a strategy map which is the visual presentation of key performance indicators, and it summarizes every strategy related to each measurement category. ${ }^{(25,26)}$ Furthermore, the results show that the airlines have basic standards for applying the BSC technique.

\section{Average Frequency of Using the BSC Perspective Measures}

Tables (3), (4), (5), and (6) illustrate the usage of the common measures among the performance measures perspectives during the BSC implementation. The most common measures found are in the financial perspective ( $81 \%$ average frequency of use), and then with less common usage are measures in the customer perspective (66\% average frequency of use), and learning and growth (61.6\% average frequency of use), while quite far away are the measures used in the internal business processes perspective (\%59.4 average frequency of use ).

These results match with the study of Porporato et al. ${ }^{(28)}$ who has concluded that decision makers tend to give a much higher weight to the financial perspective compared to other qualitative perspectives during implementing the BSC.

Table (3): Financial perspective measures average frequency of use by airline companies

\begin{tabular}{|c|c|c|c|}
\hline \multirow{2}{*}{ Financial perspective } & \multicolumn{2}{|c|}{ Companies' usage } & \multirow{2}{*}{ Average frequency of use } \\
\cline { 2 - 3 } & Count & Percentage & 100 \\
\hline Return on investment & 205 & 95 \\
\hline Operative income & 195 & 84 \\
\hline $\begin{array}{c}\text { Total revenues from different } \\
\text { line of business }\end{array}$ & 172 & 80 \\
\hline Per share measures & 164 & 92 \\
\hline Cash flow measures & 189 & 53 \\
\hline Total costs reduction & 109 & 63 \\
\hline Stock index & 129 & 92 \\
\hline Value added analysis & 189 & 95 & \multirow{2}{*}{$\mathbf{8 1 \%}$} \\
\hline Total assets utilization & 195 & 83 & \\
\hline Productivity improvement & 170 & 52 & \\
\hline Available seat mile & 107 & \\
\hline
\end{tabular}

According to Table (3), the majority of airline companies' financial objectives are mainly related to return on investment ( $100 \%$ of the sample), operative income ( $95 \%$ of the sample), total assets utilization (95\% of the sample), cash flow measures ( $92 \%$ of the sample), and value added analysis ( $92 \%$ of the sample). On the other hand, there is an ignoring to the measures of total costs reduction and available seat mile as indicators of the financial perspective; nearly half of the sample does not use them. 
Table (4): Customer perspective measures average frequency of use by airline companies

\begin{tabular}{|c|c|c|c|}
\hline \multirow{2}{*}{ Customer perspective } & \multicolumn{2}{|c|}{ Companies' usage } & \multirow{2}{*}{ Average frequency of use } \\
\hline & Count & Percentage & \\
\hline Customer satisfaction & 189 & 92 & \multirow{18}{*}{$66 \%$} \\
\hline Market share & 162 & 79 & \\
\hline Product price & 90 & 44 & \\
\hline New markets or new clients & 160 & 78 & \\
\hline Frequent flyer program & 139 & 68 & \\
\hline Flight frequency & 162 & 79 & \\
\hline Boarding time & 80 & 39 & \\
\hline Menu & 66 & 32 & \\
\hline Customer complaints & 197 & 96 & \\
\hline Destinations & 158 & 77 & \\
\hline Flights per day & 68 & 33 & \\
\hline Annual seats & 166 & 81 & \\
\hline Investment in corporate image & 180 & 88 & \\
\hline Income or sales per client or per product & 152 & 74 & \\
\hline Investments in brand development & 96 & 47 & \\
\hline Geographical coverage & 86 & 42 & \\
\hline On time delivery & 96 & 47 & \\
\hline Product quality & 189 & 92 & \\
\hline
\end{tabular}

The results in Table (4) show that airline companies, with regard to the customer perspective, have high concern to customer complaints ( $96 \%$ of the sample), customer satisfaction, and product quality measures (92\% of the sample). On the other hand, the sample units have a moderate to low concern to the other measures.

Table (5): Internal business processes perspective measures average frequency of use by airline companies

\begin{tabular}{|c|c|c|c|}
\hline \multirow{2}{*}{ Internal business processes perspective } & \multicolumn{2}{|c|}{ Companies' usage } & \multirow{2}{*}{ Average frequency of use } \\
\hline & Count & Percentage & \\
\hline Investment in information technology & 152 & 74 & \multirow{17}{*}{$59.4 \%$} \\
\hline Products' rejection rate & 129 & 63 & \\
\hline Productivity & 109 & 53 & \\
\hline Information technology uses with clients & 68 & 33 & \\
\hline Expenses or revenues per employee & 66 & 32 & \\
\hline Capacity utilization & 53 & 26 & \\
\hline On time development of products & 49 & 24 & \\
\hline Environmental issues & 115 & 56 & \\
\hline Inventory turnover & 66 & 32 & \\
\hline Product, service, or process costs & 121 & 59 & \\
\hline Cancelations & 185 & 90 & \\
\hline On-time arrivals & 150 & 73 & \\
\hline Baggage handling & 156 & 76 & \\
\hline Operating cost per available seat & 176 & 86 & \\
\hline Accidents and incidents & 86 & 42 & \\
\hline Age of aircrafts & 187 & 91 & \\
\hline Number of aircrafts & 141 & 69 & \\
\hline
\end{tabular}




\begin{tabular}{|c|c|c|}
\hline Aircrafts utilization & 178 & 87 \\
\cline { 1 - 2 } Length of passenger trips & 182 & 89 \\
\cline { 1 - 2 } Length of aircraft flights & 66 & 32 \\
\hline
\end{tabular}

Concerning the measures associated to the internal business processes perspective, it is observed that only age of aircraft ( $91 \%$ of the sample), cancellations (90\% of the sample), and length of passenger trips (89\% of the sample) measures have a high usage average.

Table (6): Learning and growth perspective measures average frequency of use by airline companies

\begin{tabular}{|c|c|c|c|}
\hline \multirow{2}{*}{$\begin{array}{c}\text { Learning and growth } \\
\text { perspective }\end{array}$} & \multicolumn{2}{|c|}{ Companies' usage } & \multirow{2}{*}{ Average frequency of use } \\
\hline & Count & Percentage & \\
\hline Employees'satisfaction & 187 & 91 & \multirow{14}{*}{$61.6 \%$} \\
\hline Training & 189 & 92 & \\
\hline New products & 193 & 94 & \\
\hline New ideas & 111 & 54 & \\
\hline Education & 123 & 60 & \\
\hline Team work & 94 & 46 & \\
\hline Empowerment & 125 & 61 & \\
\hline Remuneration & 68 & 42 & \\
\hline Continuous improvement & 168 & 82 & \\
\hline Employees' turnover & 64 & 31 & \\
\hline Seat miles per employee & 74 & 36 & \\
\hline Wages and incentives & 139 & 68 & \\
\hline Employees' initiatives & 49 & 24 & \\
\hline Performance evaluation & 166 & 81 & \\
\hline
\end{tabular}

The result in Table (6) also reveal that there are common measures used to reflect the learning and growth perspective such as, new products ( $94 \%$ of the sample), training ( $92 \%$ of the sample), and Employees' satisfaction (91\% of the sample). However, the majority of the other measures of learning and growth are unique measures used by limited number of airline companies.

\section{Determining the Main Barriers to Implementing the BSC}

First, to assess the reliability of the study factors, Cronbach's Alphai ${ }^{95}$ is calculated to test the stability of variables retained in each factor. According to the results of Table (7), the reliability analysis gave alpha coefficients exceeding (.70) for all the study factors which are regarded as acceptable reliability coefficients and a good indication of construct reliability.

Table (7): Ranking the main barriers to implementing the BSC in airline companies

\begin{tabular}{|c|c|c|c|c|}
\hline The barriers & Mean & Std. dev & Factor loading & Rank \\
\hline 1- Strategic control barriers: & 2.7 & .518 & - & \multirow{6}{*}{4} \\
\hline a- The measures of the BSC has little involvement of front line workers & 2.3 & 1.08 & 0.818 & \\
\hline b- The BSC does not reflect changes in external environments & 2.6 & 1.04 & 0.743 & \\
\hline c-T he strategy of the BSC is not formulated in a strategy map & 2.7 & 1.12 & 0.727 & \\
\hline d- The BSC inadequate feedback on continent of strategy & 3 & 1.16 & 0.704 & \\
\hline $\begin{array}{l}\text { e- It cannot balance the long-term goals and short-term goals of the } \\
\text { business }\end{array}$ & 3.3 & 1.34 & 0.852 & \\
\hline
\end{tabular}




\begin{tabular}{|c|c|c|c|c|}
\hline 2-Ambiguous validity of the cause and effect relationship barriers: & 2.8 & .727 & - & \multirow{5}{*}{3} \\
\hline $\begin{array}{c}\text { a- Improving customer perspective does not necessarily improve financial } \\
\text { outcomes }\end{array}$ & 3.1 & 1.12 & 0.867 & \\
\hline $\begin{array}{l}\text { b-Non-financial measures in the BSC are not necessarily the drives of } \\
\text { financial measures }\end{array}$ & 2.7 & 1.11 & 0.858 & \\
\hline $\begin{array}{l}\text { c- Airlines often fail to establish such casual thinking among the four } \\
\text { perspective }\end{array}$ & 3.1 & 1.30 & 0.835 & \\
\hline e- The BSC cannot help managers to improve the efficiency in operation & 2.5 & 1.09 & 0.954 & \\
\hline 3- Common measure bias: & 3.2 & 1.21 & - & \multirow[b]{3}{*}{1} \\
\hline a- Superior managers rely on common measures & 3.2 & 1.20 & 0.768 & \\
\hline $\begin{array}{l}\text { b- Unique measures are often disregarded or ignored by superior managers } \\
\text { in performance evaluation }\end{array}$ & 3.1 & 1.30 & 0.870 & \\
\hline 4- Obese and static nature: & 3.05 & .686 & & \multirow{4}{*}{2} \\
\hline a- There are many measure in the BSC system & 3.2 & 1.29 & 0.863 & \\
\hline $\begin{array}{c}\text { b- The BSC is a static model because it cannot solve the time lag } \\
\text { problem }\end{array}$ & 3.4 & 1.04 & 0.834 & \\
\hline c- The BSC does not reflect changes in internal environment & 2.5 & .888 & 0.754 & \\
\hline 5- Cultural barriers: & 2.6 & .543 & - & \multirow{4}{*}{5} \\
\hline a- Employees feel that the BSC is strict and formal & 3.4 & 1.27 & 0.818 & \\
\hline $\begin{array}{l}\text { b- Employees hesitate to participate as the BSC frame work encourages } \\
\text { low individualism }\end{array}$ & 2.2 & 1.23 & 0.792 & \\
\hline $\begin{array}{l}\text { c- With the BSC, it is difficult to have a better understanding of the } \\
\text { strategy and vision of the business }\end{array}$ & 2.2 & .910 & 0.753 & \\
\hline 6- Matching barriers: & 2.1 & .679 & - & \multirow{4}{*}{6} \\
\hline a- The BSC does not match with the existing planning system & 1.8 & .812 & 0.834 & \\
\hline a- The BSC does not match with performance measurement & 2.3 & 1.30 & 0.726 & \\
\hline c- The BSC does not match with information technology & 2.3 & .978 & 0.722 & \\
\hline 7- General requirements barriers: & 2.8 & .560 & - & \multirow{8}{*}{3} \\
\hline a- Inadequate IT support & 1.9 & .967 & 0.894 & \\
\hline b- Inadequate project team & 3.2 & 1.16 & 0.719 & \\
\hline c- Inadequate Key Performance Indicators (KPIs) & 2.7 & .923 & 0.912 & \\
\hline d- Lack of executive sponsorship & 3 & 1.14 & 0.763 & \\
\hline e- Lack of the BSC education and training & 3.1 & 1.18 & 0.734 & \\
\hline f- Lack of planning and communication & 2.9 & 1.20 & 0.787 & \\
\hline $\mathrm{g}$ - The BSC is difficult to involve in the whole organization & 3.0 & 1.25 & 0.754 & \\
\hline
\end{tabular}

Mean scale: $1 *$ strongly disagree to $5 *$ strongly agree.

According to Table (7), the analyzed data sheds light on the most critical barriers that are associated with the BSC implementation in airline companies.

When ranking these barriers, the most important barriers with the highest mean scores are "common measure bias" with 3.2 mean rating, and "obese and static nature" with 3.05 mean rating. This result may be due to that mangers have thought the implementation of the BSC does not meet their initial high expectations. Moreover, 
this result confirms the study of Lipe and Salterio ${ }^{(25)}$ who have found that superior managers tend to simplify performance measurement by only relying on common measures when they evaluate the performance of multiple subordinate units. Consequently, unique measures are often disregarded or even ignored by superior managers in performance evaluations.

The study of Libby, Salterio, \& Webb, ${ }^{(50)}$ can also explain the result as it has concluded that common measure bias does exist in performance evaluations of multiple units due to the cognitive limitations of human beings.

Many studies have investigated the obese and static nature issue, such as the study of Dilla\&Steinbart (51) which has concluded that the large number of measures in the BSC, together with the lack of normative guidelines for performance evaluations, make using the BSC a complex and relatively unstructured task. Opponents have also argued that the BSC is a static model because it cannot solve the time lag problem and does not reflect changes in external environments. ${ }^{(52)}$ Furthermore, Neely study ${ }^{(53)}$ has suggested that the implementation of an obese and static BSC system may potentially risk performance management.

In addition, the results reveal that "ambiguous validity of the cause and effect relationship barriers" and "general requirements barriers", with both 2.8 mean rating, have achieved a moderated negative effect. These results may be due to the fact that organizations often fail to establish such causal links among the four perspectives because there is little or no guidance given in the BSC literature on how to set up these causal relationships.

Nørreklit ${ }^{(47)}$ has argued that there is no cause-and-effect relationship among the four perspectives of the BSC. For example, customer satisfaction does not necessarily improve financial performance because even though customers are satisfied, they may still choose to buy from a competitor if that competitor's products are more attractive to them.

The data above illustrates that general requirements are another critical barriers that encounter airline companies to apply successful BSC. Also, "Inadequate project team" has achieved 3.2 mean rating, "lack of the BSC education and training" is with 3.1 mean rating, while "the BSC is difficult to involve in the whole organization" has achieved 3 mean rating. Furthermore, it is valuable to mention that the IT systems in many low cost companies usually provide only financial data, and thus cannot provide enough support for the implementation of the BSC. ${ }^{(21)}$

On the contrary, the barriers "strategic control" with 2.7 mean rating, "cultural barriers" with 2.61 mean rating, and "matching barriers" with 2.1 mean rating are ranked as the least critical barriers associated to the implementation of the BSC. Moreover, it has been argued that the BSC is a hierarchically top-down model that is not rooted in the organization or in the environment. Thus, it is questionable as a strategic control tool. $(47,58)$

Despite these results, under existing performance measurement systems, managers usually need to achieve several objectives, which tend to make them focus more on short-term benefits rather than on the BSC's long-term goals. Furthermore, no initiative in an organization, regardless of its potential, has any chance of success without a sponsor in the top management. However, due to its seeming simplicity, people in charge very often conclude that thorough education and training are not required. Such a conclusion will permanently harm the BSC initiative and lead to failure. Therefore, in order to create a BSC that works, and capable of implementing the company strategy, linking individuals, creating new behavior and enhancing communication, a well trained team is needed.

Broadly speaking, These results match with the results of the studies by (e.g., Nørreklit, ${ }^{(47)}$; Neely, ${ }^{(53)}$; Brignall, ${ }^{(54)}$ who have found that the BSC has unavoidable limitations and barriers as a strategic management system since the implementation of the BSC faces even more obstacles, often beyond what its users imagine. 


\section{The Kruskal-Wallis Test}

The data presented in Table (8) below shows that there is significant difference between airline companies' types and airline companies with different gross revenue in their perception of the main barriers to implementing the BSC, with respect only to the "strategic control barriers", and "general requirements". For example, it is noticed that low cost airline companies are more concerned with these barriers during the implementation. However, the different types of airline companies with different gross revenue have the same direction with respect to the barriers "ambiguous validity of the cause and effect relationship", "obese and static nature", "cultural barriers", "common measure bias", and "matching barriers".

Table (8): Testing equality of main barriers mean regarding airline companies' management characteristics (Kruskal-Wallis).

\begin{tabular}{|c|c|c|c|c|c|c|c|c|}
\hline & \multicolumn{2}{|c|}{ Airline type } & \multicolumn{2}{c|}{ Gross revenue } & \multicolumn{2}{c|}{$\begin{array}{c}\text { Measuring } \\
\text { performance } \\
\text { methods }\end{array}$} & \multicolumn{2}{c|}{$\begin{array}{c}\text { Basic standards } \\
\text { for performance } \\
\text { measurement }\end{array}$} \\
\cline { 2 - 9 } The barriers & $\begin{array}{c}\text { Value of } \\
\text { Kruskal- } \\
\text { Wallis } \\
\text { Test }\end{array}$ & Sig & $\begin{array}{c}\text { Value of } \\
\text { Kruskal- } \\
\text { Wallis } \\
\text { Test }\end{array}$ & Sig & \multicolumn{2}{|c|}{$\begin{array}{c}\text { Value of } \\
\text { Kruskal- } \\
\text { Wallis Test }\end{array}$} & $\begin{array}{c}\text { Value of } \\
\text { Kruskal- } \\
\text { Wallis } \\
\text { Test }\end{array}$ & Sig \\
\hline $\begin{array}{c}\text { 1- Strategic control } \\
\text { barriers }\end{array}$ & 18.15 & .000 & 22.80 & .000 & 14.95 & .000 & 10.36 & .498 \\
\hline $\begin{array}{c}\text { 2- Ambiguous validity } \\
\text { of the cause and effect } \\
\text { relationship barriers }\end{array}$ & 11.64 & .052 & 11.45 & .413 & 16.43 & .001 & 13.21 & .003 \\
\hline $\begin{array}{c}\text { 3- Common measure } \\
\text { bias }\end{array}$ & 15.97 & .032 & 9.09 & .022 & 10.36 & .498 & 12.782 & .308 \\
\hline $\begin{array}{c}\text { 4- Obese and static } \\
\text { nature }\end{array}$ & 17.43 & .672 & 14.22 & .011 & 6.30 & 0.098 & 11.62 & .000 \\
\hline 5- Cultural barriers & 19.71 & .623 & 2.60 & 0.457 & 16.23 & .000 & 1.05 & 0.789 \\
\hline 6- Matching barriers & 27.34 & .205 & 9.05 & .617 & 11.74 & .002 & 26.202 & .003 \\
\hline 7- General requirements & 14.02 & .000 & 28.29 & .000 & 10.21 & .413 & 11.401 & .410 \\
\hline
\end{tabular}

The data analyzed clearly states that despite using different measuring performance methods, there is no significant difference between companies' perception of the barriers to implementing the BSC with respect to "common measure bias", "obese and static nature", and "general requirements". However, there is significant difference in "strategic control barriers", "ambiguous validity of the cause and effect relationship barriers", " cultural barriers", and "matching barriers" as obstacles during the implementation of the BSC. This result may be due to the different conditions affecting the business flow which generally affect the general vision and perception of the company.

Additionally, the previous table presents further data analysis to show whether the obtained results are restricted to particular basic standards or not. Surprisingly, the Kruskal-Wallis analysis indicates that there is a significant difference between companies with different basic standards, with respect only to the barriers "ambiguous validity of the cause and effect relationship", "obese and static nature", and "matching barriers". This result may be due to the fact that implementing the BSC needs to follow many initial stages and basic standards to guarantee its success. 


\section{Conclusion and Managerial implications}

The Balanced Scorecard (BSC) tries to translate a company's strategic direction and objectives into actionable initiatives and measurements. Using only financial measurement is not enough to drive an organization. A balanced view includes at least four perspectives: financial, customers, internal business processes, and learning and growth; they are linked together as part of a chain driving to the organizational outcomes. Moreover, the measures incorporated in the BSC provide a balance between the outcome measures and the performance drivers, as well as a balance between internal and external measures. ${ }^{(21)}$

Despite its worldwide popularity and its recognition as a powerful management tool, the BSC is not always implemented successfully. Although many organizations have adopted the BSC, a great number of them have encountered problems when trying to introduce the concept in their business. ${ }^{(21)}$

Although the BSC can help airlines to achieve better results when compared to traditional performance measurement system, there are numerous possible barriers and threats that deserve increased attention from both researchers and top managers.

This study contributes to the general BSC implementation literature by determining critical barriers to implementing the BSC in airlines. In addition, the research aims at exploring the areas with the critical measures which are difficult to be applied and need more attention during implementing the BSC. Moreover, the findings of this study have practical implications. For airlines' executives and managers, the results may be interesting and useful for their decision-making with regard to implementing the BSC.

Based on the data analysis, in the airlines, the usage of the common measures among the performance measures perspectives during the BSC implementation indicates that the most common measures found are in the financial perspective, then with less common usage come the measures in the customer perspective and learning and growth, while quite far away are the measures used in the internal business processes perspective.

Furthermore, the data analyzed sheds light on the most critical barriers that are associated with implementing the BSC in airline companies. Besides, when ranking these barriers, it is found that the most important barriers are "common measure bias" and "obese and static nature". In addition, the results reveal that "ambiguous validity of the cause and effect relationship barriers" and "general requirements barriers" have achieved a moderated negative effect. On the contrary, the barriers "strategic control", "cultural barriers", and "matching barriers" are ranked as the least critical barriers associated with the implementation of the BSC.

In addition, the results send a meaningful message to airlines managements. They should concentrate on facing the barriers associated with implanting the BSC. Top managements should also utilize both common and unique measures to properly evaluate performance. Furthermore, airlines should have more attention to overcoming the obese and static nature of the BSC by modifying its measures according to the airlines' needs. They can avoid putting too many measures in one BSC setup. According to psychological research, an individual is only capable of handling around seven measures simultaneously. They also should do moderated efforts to present a well designed strategy map. Moreover, comprehensive business analysis is essential to make the causeand effect relationship in the BSC framework effective. Besides, the general requirements which help in applying the BSC should be presented. There is also no serious need for airlines to show their efforts in strategic control, cultural, and matching barriers. However, managers should prepare to overcome cultural barriers. Furthermore, a detailed and feasible strategic plan and well-designed strategy map are prerequisites of a successful BSC implementation. Finally, a competent IT system is fundamental for implementing the BSC successfully and translating the airline's vision into clear measurable outcomes that define success, and that are shared throughout the airlines and with customers and stakeholders.

The results also show that there is significant difference between airline companies' types and airline companies with different gross revenue in their perception of the main barriers to the implementation of the BSC, with respect only to the "strategic control barriers", and "general requirements". Furthermore, using different measuring performance methods reflects a significant difference in "strategic control barriers", 
"ambiguous validity of the cause and effect relationship barriers", " cultural barriers", and "matching barriers" as obstacles during the implementation of the BSC. There is also a significant difference between companies with different basic standards, with respect only to the barriers "ambiguous validity of the cause and effect relationship", "obese and static nature", and "matching barriers".

This research provides a number of important contributions to the performance measurement theory and airlines managements. However, managers and researchers who wish to use the results in relation to specific strategic decisions should note several characteristics of the study that may limit its applicability. Further research is clearly needed. For example, there may be still some other barriers to the implementation of the BSC that have not been identified in the conceptual framework of this study. This research focuses only on the perception of the airlines' top managers and does not measure the perceptions of employees regarding the barriers to implementing the BSC. Moreover, the technique used in the current study is restricted by the sample size. Therefore it is recommended to enlarge the sample size in further studies. It is also valuable to choose other types of airlines in order to have a more comprehensive view. Furthermore, it would be useful to examine feedback of the airlines who have achieved success in using the BSC system as tool for performance management.

\section{Reference}

(1) Quintano, A. ( 2010) Performance evaluation in the hospitality industry : the balanced scorecard and beyond, available at: http://www.icabr.com/fullpapers/Quintano\%20Alfred.pdf [Accessed on $23^{\text {th }}$ June 2014].

(2) Chytas, P., Glykasb, M., and George Valiris, G. (2011) A proactive balanced scorecard. International Journal of Information Management, 31, 460- 468.

(3) Yap, C., Siu, E., Baker, G. R., Brown, A. D., and Lowi-Young, M. P. (2005) A comparison of system wide and hospital-specific performance measurement tools/practitioner application. Journal of HealthcareManagement, 50 (4).251-62.

(4) Papalexandris, A., Ioannou, G., Soderquist, E. and Prastacos G.P. (2005) A Holistic methodology for Putting the Balanced Scorecard into Action, European Management Journal, 23, (2 ), 214-227.

(5) Braam, G.J.M. and Nijssen, E.J. (2004) Performance effects of using the Balanced Scorecard: a note on the Dutch experience, Long range planning, 37, (4),335-349.

(6) Frigo, M., \& Krumwiede, K. R. (2000) The balanced scorecard: A winning performance measurement system. Strategic Finance, 81(7), 50-54.

(7) Atkinson A., Epstein M. (2000) Measure for Measure: Realizing the power of the balanced scorecard. CMA Management, 23-28.

(8) Kartalis, N., Velentzas,J.and Broni, G. (2013) Balance Scorecard and Performance Measurement in a Greek Industry International, Conference on Applied Economics (ICOAE) 2013Procedia Economics and Finance, 5, 413 - 422.

(9) Wang,Y., Li,Y., Jan, C. and Chang, K. (2013) Evaluating Firm Performance with Balanced Scorecard and Data Envelopment Analysis WSEAS TRANSACTIONS , Business and economics ,1 (10), 24-39.

(10) Borza,A.and . Bordean ,O. ( 2006 )Performance measuring of tourism small medium -size enterprise, International Conference on Business Excellence27-28 October, 2006, Brasov, Romania.

(11) Rafati, D. ( 2011 ) The Impact of Expectation \& Perception on Customer Satisfaction in Airline Industry (A Case Study of Mahan Air), master thesis, Sharif University of Technology International Campus.

(12) Procurement Executives' Association (2003) Guide to a Balanced Scorecard: Performance Management Methodology, available at: http://energy.gov/sites/prod/files/maprod/documents/BalancedScorecardPerfAndMeth.pdf [ Accessed on $4^{\text {th }}$ December 2014].

(13) Asif, M., Bresson, C. and Moskowitz, M. (2007) It Framework for the Implementation of Balanced Scorecard in Healthcare Systems, Nesug, 11(14), 1-12.

(14) Bisbe, J. and Barrube , J.(2012) The balanced scorecard as a management tool for assessing and monitoring strategy implementation in health care organizations, Healthcare Managements, 65 (10). 919-927.

(15)Max Houck, M., Speaker, P., Fleming, A. and, Riley, R.. (2012) The balanced scorecard: Sustainable performance assessment for forensic laboratories, Science and Justice, 52, 209-216 
(16) D. C. Frechtling, C. (2010) A balanced scorecard system for management strategy and measuring performance of destination management organization. Available at: http://home.gwu.edu/ frechtli/material/BSCWorkingPaper4-06.pdf [Accessed on $5^{\text {th }}$ march 2015].

(17) Kaplan, S.E. and Wisner, P.S., (2009) The judgmental effects of management communications and a fifth balanced scorecard category on performance evaluation, Behavioral Research in Accounting, 21(2),. 37-56.

(18) Kaplan, R.S. and Norton, D.P., (2001) Transforming the balanced scorecard from performance measurement to strategy management: part 1, Accounting Horizons, 15 (1), 87-104.

(19) Vanti ,A., Espin, R., Soltero, A. and Ciotta,D.(2008) Strategic Themes For Balanced Scorecard Construction Based On Fuzzy Logic, The International Journal of Applied Management and Technology, 6 ( 2),4-38

(20) Ionescu, M. (2012) The Balanced Scorecard (BSC). Framework, Implementation Methodology and Recommended Application, Executive Brief, Romania, (April 2012).

(21) Dragan Pujas ,D.( 2010 ) Barriers to the Successful Implementation of the Balanced Scorecard - the Case of Plava Laguna J.S.C. Master thesis, Modul University, Vienna.

(22) Kaplan, R. S. and Norton, D. P. (1996) Using the balanced scorecard as a strategic management system, Harvard Business Review, January-February, pp. 37-48.

(23) Ivanov ,C.and Avasilcăi ,S.(2014 ) Measuring the performance of innovation processes: A BalancedScorecard perspective2nd World Conference On Business, Economics And Management -WCBEM 2013Procedia - Social and Behavioral Sciences, 109 , 1190 - 1193.

(24) Sainaghi,R., Phillips P, Corti, V, Sainaghi,R., Paul Phillips ,P. and Cort,i V.( 2013) Measuring hotel performance: Using a balanced scorecard perspectives' approach ,International Journal of Hospitality Management. 34 (2013), 150159.

(25) Lipe ,M. and Salterio, S.(2000)The balanced scorecard :judgmental effect of common and unique performance measures, The accounting review,75 (3), 283-298.

(26) Stewart, A. and Hubin, J. (2001) The balanced scorecard beyond reports and rankings, Planning for Higher Education, 37-42.

(27) Schaltegger, S. and Freun,F. (2011) The Sustainability Balanced Scorecard Concept and the Case of Hamburg Airport, Centre for Sustainability Management (CSM) Leuphana University, Lüneburg.

(28) Porporato, M., Basabe, M., and Arellano, J.(2008) Commonality and Standardization of Balanced Scorecard's Measures across Perspectives. Revista del Instituto Internacional de Costos, ISSN 1646-6896, n 2, enero/julio 2008.113131.

(29)Andra, G. and Robert N.(2006) Entrepreneurs use a Balanced Scorecard to translate strategy into performance measures. Journal of Small Business Management, 44,.407- 425.

30) Fletcher, H. D., \& Smith, D. B. (2004) Managing for value: Developing a performance measurement system integrating economic value added and the Balanced Scorecard in strategic planning. Journal of Business Strategies, 21, 1-17.

(31) Rickards, R. C. (2007) BSC and benchmark development for an e-commerce SME. Benchmarking, 14, $222-250$.

(32) Banker, R. D., Potter, G., \& Srinivasan, D. (2000) An empirical investigation of an incentive plan that includes nonfinancial performance measures. Accounting Review, 75 (1), p.65-92.

(33) Kaplan RS, Norton DP. Alignment (2006) Using the balanced scorecard to create corporate synergies. Boston, MA: Harvard Business School Press.

(34) Druckenmiller DA and Acar W.(2009) An agent-based collaborative approach to graphing causal maps for situation formulation. J Assoc Inf Syst2009; 10 (Special Issue), 221-51.

(35) Banker, R. D., Chang, H., \& Pizzini, M. J. (2004) The balanced scorecard: Judgmental effects of performance measures linked to strategy. Accounting Review, 79 (1), p.1-23.

(36) Neves, J., \& Lourenco, S. (2008) Performance evaluation of worldwide hotel industry using data envelopment analysis: Global case in hospitality industry. New York, NY: Haworth Press.

(35) Chen, T., \& Chen, L. (2007) DEA performance evaluation based on BSC indicators incorporated: The case of semiconductor industry. International Journal of Productivity and Performance Management, 56 (4), p.335-357.

(36) Eilat H., Golany, B., \& Shtub, A. (2008) R\&D project evaluation: An intergrade DEA and Balanced Scorecard approach. Omega, 36, 895-912.

(37) Najafi, E., Aryanegad, M., Lotfi, F., \& Ebnerasould, A. (2009) Efficiency and effectiveness rating of organization with combined DEA and BSC. Applied Mathematical Sciences, 3, p.239-265.

(38) Zeng ,K.,, i Luo, X. (2013) The balanced scorecard in China: Does it work? Business Horizons (2013) 56, 611-620.

(39) Othman, R., Ahmad Domil, A. K., Che Senik, Z., Abdullah, N. and Hamzah, N. (2006) A case study of balanced scorecard implementation in a Malaysian company, Journal of Asia-Pacific Business, 7 ( 2) 55-72.

(40) Othman, R. (2007) Enhancing the effectiveness of the balanced scorecard with scenario planning, International Journal of Productivity and Performance Management, 57 (3). 259 - 266.

(41)Othman, R. (2009) How the Balanced Scorecard can fail: Some caves, Borneo Bulletin, June 2, 2009. 
(42) Olve, N. G., Petri, C. J., Roy, J. and Roy, S. (2003) Making Scorecards Actionable: Balancing Strategy and Control, John Wiley \& Sons Ltd.

(43) Atkinson, H. (2006) Strategy implementation: A role for the Balanced Scorecard? Management Decision, 44 (10). 1441-1460.

(44) Niven, P. (2006) Balanced Scorecard Step-by-Step: Maximizing Performance and Maintaining Results, 2nd ed., John Wiley \& Sons, New York.

(45) Niven, P. (2005) Balanced Scorecard Diagnostics: Maintaining Maximizing, John Wiley \& Sons, New Jersey

(46) Ittner, C. D., \& Larcker, D. F. (2003) Coming up short on nonfinancial performance measurement. Harvard Business Review, 81(11), 88-95.

(47) Nørreklit, H. (2000) The balance on the balanced scorecard: A critical analysis of some of its assumptions. Management Accounting Research, 11(1), 65-88.

(48) SPSS. (2007) SPSS missing value analysis 16.0. Chicago, IL: SPSS Inc.

(49)Kaplan, R.S. and Norton, D.P.,(1992) The balanced scorecard - measures that drive performance", Harvard Business Review, Jan.-Feb., 1992, 72-84.

(50) Libby, T., Salterio, S. E., \& Webb, A. (2004) The balanced scorecard: The effects of assurance and process accountability on managerial judgment. Accounting Review, 79 (4), 1075-1094.

(51) Dilla, W. N., \& Steinbart, P. J. (2005) Relative weighting of common and unique balanced scorecard measures by knowledgeable decision makers. Behavioral Research in Accounting,

$17,43-53$.

(52) Veen-Dirks, V. P., \& Wijn, M. (2002) Strategic control: Meshing critical success factors with the balanced scorecard. Long Range Planning, 35(4), 407-427.

(53) Neely, A. D. (2005. The evolution of performance measurement research: Developments in the last decade and a research agenda for the next. International Journal of Operations and Production Management, 25 (12), $1264-1277$.

(54) Brignall, S. (2002 ) The balanced scorecard: An environmental and social critique. In Proceedings of the 3rd International Conference on Performance Measurement, Boston.

(55) Berman,A. (2001) Essential statistics for public managers and policy analysis, CCE press ,p .146.

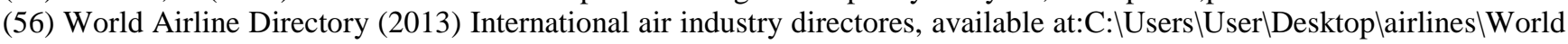
Airline Directory - the complete database of all of the world's airlines.mht.[accessed on 22th march,2014]

(57) Yin, R. (2003) Case Study Research: Design and Methods (3rd ed.), Sage, Thousand Oaks, CA.

(58) Simons, R. (2000) Performance measurement and control systems for implementing strategy. Upper Saddle River, NJ: Prentice Hall.

\section{المعوقات الرئيسية لنجاح تطبيق نظام بطاقة الأداء المتوازن : منظور شركات الطيران}

لقد ذكرت كل من المر اجع الأدبية والممارسات الإدارية السابقة أن بطاقة الأداء المتوازن (BSC) هي أداة إدارة يمكنها أن تساعد المنظمات علي تتفيذ استر اتيجيات فعالة. وعلي الرغم من شهرتها في جميع أنحاء العالم، والاعتر اف إنها بها كأداة قوية في الإدارة، إلا أن استخدامها لم يكن ناجحا

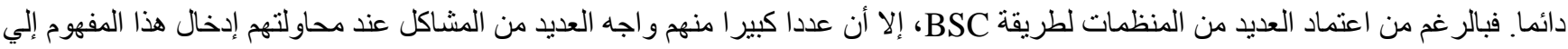

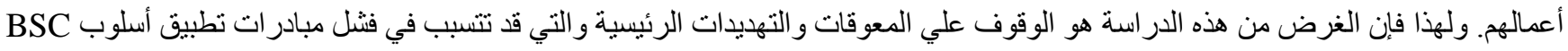
في مجال صناعة الطيران. كما يهدف البحث أيضا إلي تحديد المقاييس الهامة والتي يصعب تطوف تطبيقها وتحتاج إلي المزيد من الاهتمام عند تطبيق أسلوب BSC. ومن أجل تحقيق أهداف البحث، تم تصميم استمارة استبيان ونوزيع 312 منها في 104 شركة طيران عن طريق البريد الإلكتروني،

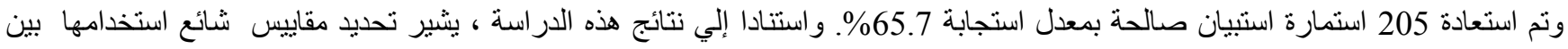
مناظير مقاييس الأداء خلال تتفيذ أسلوب BSC إلي أن المقاييس الأكثر استخداما توجد في المنظور المالي، ثم تأتي المقاييس الأقل استخداما في

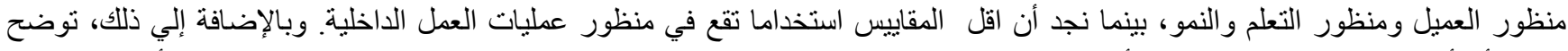
النتائج أن أهم المعوقات الرئيسية لتنفيذ أسلوب BSC هي "التحيز للمقاييس الثائعة" و "الطبيعة الثابتة والضخمة للنموذج". كما أظهرت الظهرت النتائج

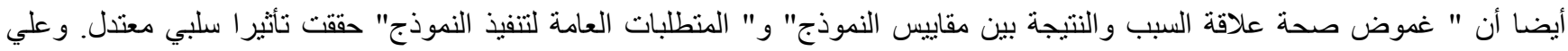
النقيض تم تصنيف "معوقات التحكم الاستر اتيجي" و"المعوقات الثقافية" و "معوقات التطابق" علي أنها أقل المعوقات أهمية. 